\title{
Effect of ALS IgG on Motor Neurons in Organotypic Spinal Cord Cultures
}

\author{
Bin Li, Xiao-Yun Liu, Zhe Li, Hui Bu, Meng-Meng Sun, \\ Yan-Su Guo, Chun-Yan Li
}

\begin{abstract}
Objective: Reports about the role of autoimmunity in amyotrophic lateral sclerosis (ALS) are inconsistent. The aim of this work was to investigate the effect of IgG from patients with ALS on motor neurons in a physiological-like surrounding. Methods: Using affinity chromatography, IgG from six ALS patients, four disease controls and five healthy subjects was purified. Organotypic spinal cord cultures, which conserve the structure of the spinal cord in a horizontal plane and are suitable for studies with long-term treatment, were used and IgG with different concentrations ranging from $0.05 \mathrm{mg} / \mathrm{mL}$ to $0.5 \mathrm{mg} / \mathrm{mL}$ was added to the culture medium. Ventral motor neuron survival was evaluated by morphology and SMI-32 immunohistochemistry staining. Lactate dehydrogenase (LDH) level in the culture medium was measured by colorimetry. Results: After cultures were treated with ALS IgG for three weeks, the number and morphology of motor neurons showed little change. In addition, there was no significant difference in lactate dehydrogenase release between cultures treated with medium alone, normal control IgG, disease control IgG or ALS IgG. Conclusions: The results indicate that IgG from these ALS patients was insufficient per se to induce motor neuron death in organotypic slice cultures. However, this does not preclude the possibility that other changes may have occurred in the motor neurons. This work offered a new model to evaluate the role of $\operatorname{IgG}$ in the pathogenesis of ALS. Organotypic cultures contribute to study of the impact of IgG on motor neurons by mimicking physiological conditions.
\end{abstract}

RÉSUMÉ: Effet de la SLA sur des neurones moteurs en culture organotypique de moelle épinière. Objectif : Les données sur le rôle de l'autoimmunité dans la genèse de la sclérose latérale amyotrophique (SLA) sont contradictoires. Le but de cette étude était de déterminer quels sont les effets d'IgG provenant de patients atteints de SLA sur des neurones moteurs dans un milieu simulant le milieu physiologique. Méthodes : Des IgG provenant de six patients atteints de SLA, de quatre patients atteints d'autres maladies et de cinq sujets sains ont été purifiées par chromatographie d'affinité. Des cultures organotypiques de moelle épinière qui conservent la structure de la moelle épinière sur un plan horizontal et qui sont adéquates pour des études à long terme, ont été utilisées. Des IgG à différentes concentrations, allant de $0,05 \mathrm{mg} / \mathrm{mL}$ à $0,5 \mathrm{mg} / \mathrm{mL}$, ont été ajoutées au milieu de culture. La survie des neurones moteurs antérieurs a été évaluée par examen morphologique et par coloration immunohistochimique au SMI-32. Le niveau de déshydrogénase lactique (DHL) dans le milieu de culture a été mesuré par colorimétrie. Résultats : Le nombre et la morphologie des neurones moteurs étaient pratiquement inchangés après trois semaines de traitement des cultures par des IgG provenant de patients atteints de SLA. De plus, il n'existait pas de différence significative dans la libération de DHL entre les cellules cultivées dans le milieu de culture sans ajout, le milieu de culture contenant des IgG de sujets témoins normaux, le milieu de culture contenant des IgG de patients atteints d'autres maladies et le milieu de culture contenant des IgG de patients atteints de SLA. Conclusions : Ces résultats indiquent que les IgG des patients atteints de SLA n'étaient pas suffisantes pour induire la mort de neurones moteurs en cultures organotypiques de coupes de tissus. Cependant, ceci n'exclut pas la possibilité que d'autres changements étaient présents dans les neurones moteurs. Cette étude représente un nouveau modèle pour évaluer le rôle des IgG dans la pathogenèse de la SLA. Les cultures organotypiques contribuent à l'étude de l'impact des IgG sur les neurones moteurs en imitant les conditions physiologiques.

Can. J. Neurol. Sci. 2008; 35: 220-225

Amyotrophic lateral sclerosis (ALS) is a chronic progressive neurodegenerative disease characterized by selective loss of motor neurons in the motor cortex, certain motor cranial nuclei and in the anterior horn of the spinal cord. The exact mechanisms underlying the disease remain unclear. Some evidence suggests that immune-mediated mechanisms may play a role in the pathogenesis of ALS. ${ }^{1}$ Human autopsy material demonstrates that IgG is found in motor neurons of the spinal cord and in pyramidal cells within the motor cortex of ALS patients. ${ }^{2}$ In the human mutant SOD1 ${ }^{\mathrm{G} 93 \mathrm{~A}}$ transgenic mice, IgG and Fc $\gamma \mathrm{RI}$ reactivities were detected in motor neurons as early as 40 days and on microglial cells at later stages. ${ }^{3}$ Moreover, several autoantibodies were identified in ALS, including antibodies against ganglioside GM1, ${ }^{4}$ voltage-gated calcium channels, ${ }^{5,6}$ neurofilaments ${ }^{7}$ and Fas. ${ }^{8,9}$ Passively transferred IgG from ALS

From the Department of Neurology (BL, XYL, ZL, HB, MMS, YSG, CYL), the Second Hospital of Hebei Medical University, Shijiazhuang; Institute of Cardiocerebrovascular Disease (XYL, HB, YSG, CYL), Shijiazhuang, Hebei, People's Republic of China.

Received August 31, 2007. Final Revisions Submitted December 18, 2007. Correspondence to: Chun-Yan Li, Department of Neurology, the Second Hospital of Hebei Medical University, Institute of Cardiocerebrovascular Disease, Hepingxi Road 215, Shijiazhuang, Hebei, People's Republic of China, 050000. 
patients increased the intracellular calcium and induced ultrastructural changes in motor neurons. ${ }^{10-13}$ In addition, IgG from patients with ALS without complement was shown to induce cell death in motoneuron-neuroblastoma hybrid cells possibly by a mechanism involving calcium. ${ }^{14,15}$ When using mixed primary spinal cord cell cultures, ALS IgG itself can induce apoptosis selectively in motor neurons. ${ }^{16}$

However, other studies produced conflicting results. Arsac et al did not detect antibodies to voltage-gated calcium channels, ${ }^{17}$ and similar results were obtained by Drachman and colleagues. ${ }^{18}$ Nyormoi presented evidence that diethyl-laminoethyl cellulose (DEAE)-purified ALS IgG might be contaminated with proteolytic activity and that the blocking of monoclonal antibody binding to the $\alpha 1$ subunit by ALS IgG was prevented by serine protease inhibitors. ${ }^{19}$ Furthermore, immunosupressants generally fail to ameliorate disease progression. ${ }^{18}$ Therefore, it is necessary to further explore the effect of ALS IgG on motor neurons.

In previous in vitro experiments, cell line or primary cell culture was used to study whether ALS IgG caused cytotoxicity in motor neurons. However, when one is interested in knowing the effect of long-term treatment with toxic substances on motor neurons, single motor neuron culture may not be the best model. ${ }^{20}$ Spinal cord organotypic cultures preserve an in vivo horizontal architecture, leaving motor neurons in situ, with all the other cells and connections in place. Moreover, the motor neurons in an organotypic culture system can survive for more than three months. ${ }^{21,22}$ Organotypic slice cultures were therefore used in the present study.

The aim of our study was to investigate the effect of IgG from ALS patients on motor neuron survival in organotypic spinal cord cultures.

\section{MATERIALS AND METHODS}

\section{Subjects and sera}

Sera were collected from six patients (three males and three females), who were clinically and electromyographycally diagnosed as having sporadic ALS according to El Escorial criteria (1994). The average patient age at sampling was 50.7 years (range 43-61 years), and the average duration of the disease was 4.6 years (ranging from one year to nine years). Two patients had clinical onset of ALS in the arms and four had leg onset. Disease control sera (DC) were taken from two patients with Guillain-Barré syndrome (GBS; one male and one female) and two patients with cerebral infarction (CI; one male and one female), in the age ranging from 37 to 64 years, with an average of 48.5 years. Normal control sera (NC) were collected from five healthy volunteers (five males and one female) with an average age of 45.4 years (ranging from 43 to 54 years). Informed consent was obtained from all patients and this study was approved by the hospital science and ethics committee.

\section{IgG purification}

IgG was purified from the sera by affinity chromatography using protein $\mathrm{G}$ (Biosynthesis Biotechnology Co. Ltd., Beijing, China), with an elution step using $100 \mathrm{mmol} / \mathrm{L}$ glycine- $\mathrm{HCl}$ buffer ( $\mathrm{pH}$ 2.7) and 16 hour (h) dialysis against phosphate buffered saline (PBS; $\mathrm{pH}$ 7.4). The purity of IgG was more than 96 percent as determined by high-performance liquid chroma- tography (HPLC). Protein concentrations were measured using an BCA protein assay Reagent Kit (Biosynthesis Biotechnology Co. Ltd., Beijing, China).

\section{Organotypic spinal cord cultures}

Animal experiments were performed according to the regulation of laboratory animal management promulgated by the Ministry of Science and Technology of the People's Republic of China [1988] No.134, which conform to internationally recognized National Institute of Health $(\mathrm{NIH})$ guidance for care and use of laboratory animals. Organotypic spinal cord cultures were prepared as described previously. ${ }^{21,23}$ Briefly, seven-day old neonatal Sprague-Dawley rats (Animal Center of Hebei Medical University) were decapitated and their lumbar spinal cords were removed. Nerve roots and excessive tissues were removed in sterile Gey's balanced salt solution containing $6.4 \mathrm{mg} / \mathrm{mL}$ of glucose. Spinal cords were then sectioned transversely at 350$\mu \mathrm{m}$ intervals with a tissue chopper (Mickle Laboratory Engineering Co. Ltd., Surrey, UK). Slices were placed on the surface of $30-\mathrm{mm}$ Millicell-CM porous $(0.4 \mu \mathrm{m})$ membrane inserts (Milliipore, Bedford, MA). The inserts were placed in a 6-well culture plate containing $1 \mathrm{~mL}$ of culture medium consisting of $50 \%$ minimal essential medium with $25 \mathrm{mmol} / \mathrm{L}$ HEPES (4-(2-Hydroxyethyl, piperazine-1-ethanesulfonic acid), $25 \%$ heat-inactivated horse serum, 25\% Hanks' balanced salt solution (Gibco, Grand Island, NY) supplemented with 25.6 $\mathrm{mg} / \mathrm{mL}$ of $\mathrm{D}$-glucose and $2 \mathrm{mmol} / \mathrm{L}$ glutamine. The slices were incubated at $37^{\circ} \mathrm{C}$ in a humidified atmosphere containing $5 \%$ $\mathrm{CO}_{2}$. All cultures were used in experiments after one week in vitro. Culture media along with $\mathrm{ALS} / \mathrm{DC} / \mathrm{NC} \mathrm{IgG}$ at various concentrations $(0.05,0.1,0.2,0.3$ or $0.5 \mathrm{mg} / \mathrm{mL})$ were changed biweekly for additional three weeks. Each concentration of every IgG was tested using at least three rats cultures.

\section{Immunohistochemistry}

For the labeling of neurons in spinal cord slices, the cultures were fixed for 30 minutes with $4 \%$ paraformaldehyde at room temperature (RT), rinsed with phosphate buffer (PB), and then rinsed three times with Tris buffered saline (TBS). After blocking for $1 \mathrm{~h}$ in TBS with $10 \%$ horse serum, the cultures were stained overnight at $4^{\circ} \mathrm{C}$ with SMI-32 monoclonal antibody (1:4000, Sternberger Monoclonals, Lutherville, MD) diluted in TBS containing $0.5 \%$ Triton X-100. After several washings with TBS containing $0.3 \%$ Triton X-100, the cultures were incubated with a biotinylated secondary antibody (1:1000, Vector Laboratories, Burlingame, CA) in TBS containing $0.3 \%$ Triton $\mathrm{X}-100$ for $1 \mathrm{~h}$ at RT and then with avidin-biotin complex reagents (1:200, Vector Laboratories, Burlingame, CA) in TBS for $1 \mathrm{~h}$ at RT. Diaminobenzidine hydrogen peroxide reaction was used for development.

SMI-32 was expressed primarily in the perikarya and dendrites of neurons, and motor neurons were clearly labeled by strong SMI-32. Motor neurons were identified by three criteria: immunostaining with SMI-32, size greater than $25 \mu \mathrm{m}$, and localization to the ventral gray region of spinal cord..$^{22}$

\section{Lactate dehydrogenase $(\mathrm{LDH})$ release assay}

Cytotoxic damage of whole slice cultures was assessed by measurement of LDH into culture medium. After spinal cord 
slices were cultured for four weeks, the culture medium was collected. The amount of LDH in the medium was determined using a LDH cytotoxicity Detection Kit (Jiancheng Bioengineering Institute, Nanjing, China) according to the manufacturer's instructions. The absorbance at $440 \mathrm{~nm}$ was determined using a Synergy HT Microplate Reader (BioTek Instruments, Winooski, VT), which was adjusted by background reading.

\section{Statistical analysis}

Data are expressed as mean \pm SEM. Statistical analysis was carried out using analysis of variance (ANOVA) with 0.05 as the significance level.

\section{RESULTS}

\section{Effect of IgG from ALS patients on motor neurons in organotypic slices}

At $\mathrm{IgG}$ concentrations ranging from $0.05 \mathrm{mg} / \mathrm{mL}$ to 0.5 $\mathrm{mg} / \mathrm{mL}$ (treated for three weeks), the number of motor neurons did not differ significantly among the four treatment groups, including medium alone, NC IgG, DC IgG or ALS IgG $(P>$ 0.05 ; Figures 1 and 2). As for IgG from the same source, the number of motor neurons did not change with increasing $\mathrm{IgG}$ concentration $(P>0.05)$. After treatment with NC/DC/ALS IgG for three weeks, SMI-32 positive neurons showed little morphological change (Figure 3). The general structure of the spinal cord slices was conserved and the thick neuritis of motor neurons stretched smoothly (Figures 1 and 3).

\section{Effect of IgG treatment on $\mathrm{LDH}$ release from organotypic slice}

Lactate dehydrogenase efflux to the culture medium has been used as a general and quantitative measure of cell lysis in vitro, and it is also a useful marker for neuronal degeneration in organotypic slice cultures. ${ }^{24}$ Therefore, the amount of cell injury/death was further assessed by measuring $\mathrm{LDH}$ release from cultures. There was no significant difference in LDH release among cultures treated with medium alone, $\mathrm{NC} \mathrm{IgG,} \mathrm{DC}$ IgG or ALS IgG for three weeks $(P>0.05$; Figure 4$)$. With increased $\mathrm{IgG}$ concentrations, the amount of $\mathrm{LDH}$ release did not differ significantly among groups treated with $\mathrm{NC} \mathrm{IgG,} \mathrm{DC} \mathrm{IgG}$ or ALS IgG $(P>0.05$; Figure 4$)$.
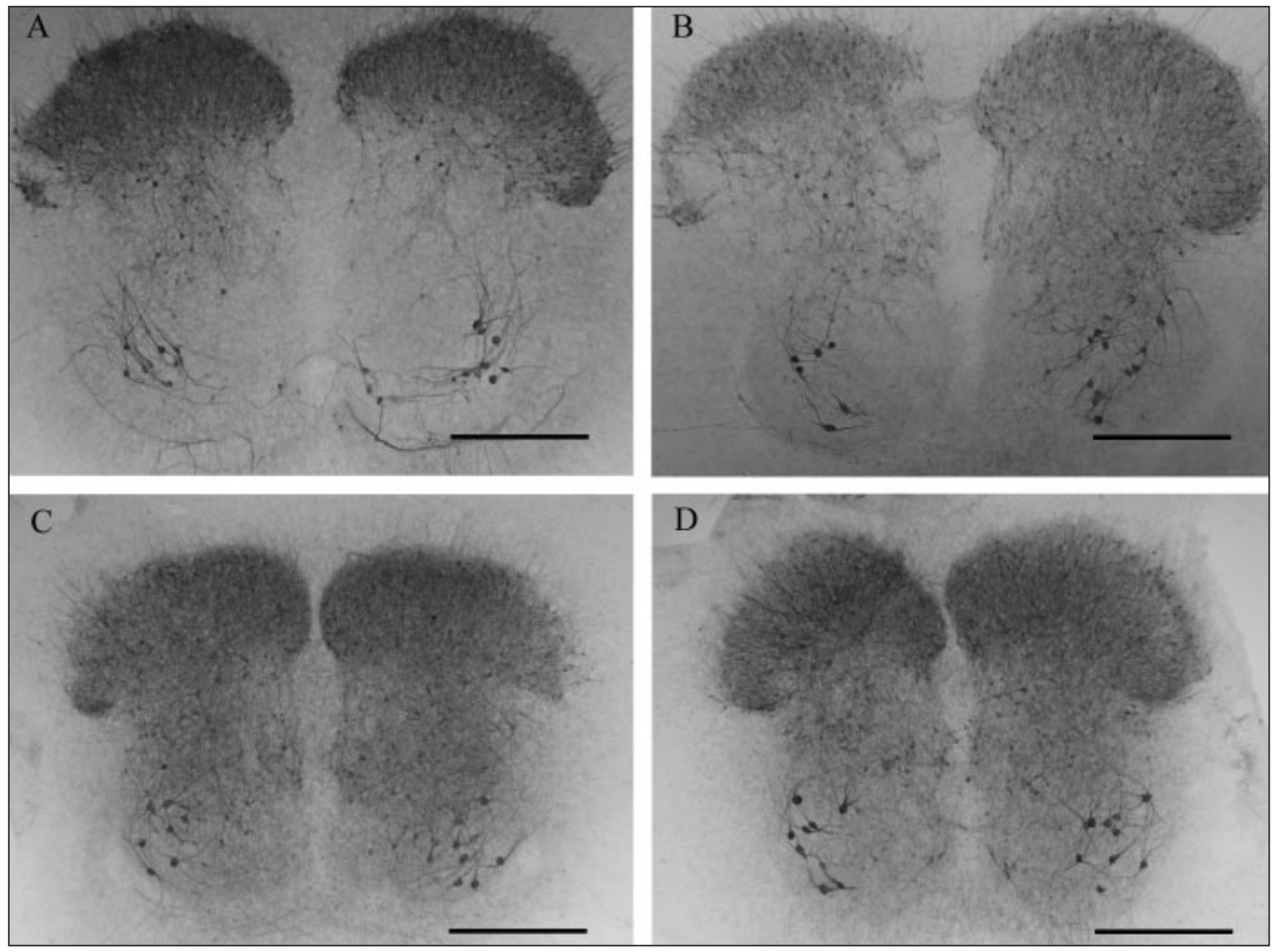

Figure 1: SMI-32-immunostaining of whole slice culture treated with medium alone (A), $0.5 \mathrm{mg} / \mathrm{mL} N C \operatorname{Ig} G(B), G B S \operatorname{Ig} G$ (C) or ALS IgG $(D)$ for three weeks. The media as well as the purified IgG were changed biweekly. Large, strongly SMI-32positive motor neurons gathered in the ventral horn. NC, normal control; GBS, Guillain-Barré syndrome; ALS, amyotrophic lateral sclerosis. All were the same magnification. Scale bar $=500 \mu \mathrm{m}$. 


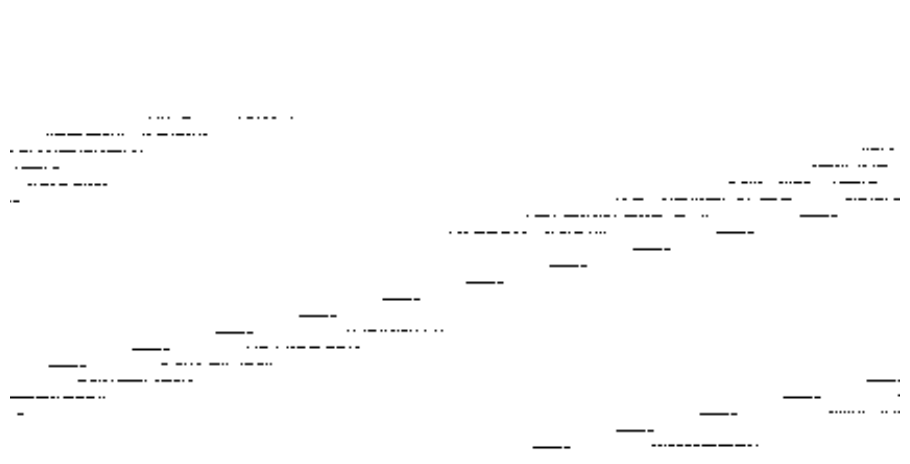

Figure 2: Motor neuron number in organotypic slice cultures treated with medium alone, NC IgG, DC IgG or ALS IgG for three weeks. The media as well as the purified IgG were changed biweekly. Data are expressed as mean \pm SEM. Medium alone, $n=8 ; N C \operatorname{IgG}, n=5 ; D C$ $\operatorname{Ig} G, n=4 ; A L S \operatorname{Ig} G, n=6$. Each IgG at per concentration was tested on ten slices from three rats cultures. $N C$, normal control; $D C$, disease control; ALS, amyotrophic lateral sclerosis.

\section{Discussion}

The role of autoimmunity in ALS remains controversial. Using organotypic culture prepared from neonatal rat lumbar spinal cord, the present study investigated whether IgG isolated from patients with ALS caused cell death. Our results showed that 0.05 to $0.5 \mathrm{mg} / \mathrm{mL} \mathrm{IgG}$ from these six ALS patients were insufficient per se to induce motor neuron death in organotypic spinal cord slice culture. Nevertheless, our study provided a new way to study the effect of $\mathrm{IgG}$ on motor neurons.

In previous reports, the effect of ALS IgG on motor neurons was studied either in cell lines $s^{8,14,15}$ or in mixed primary cell cultures, ${ }^{8,16}$ in which tissue architecture was not preserved and the treatment was short. In addition, glial cells take an active part in a series of physiological and pathological processes. Thus, it is necessary to consider the effect of glia in in vitro study. Organotypic slice cultures are closer to the in vivo structure and can be maintained with appropriate morphological features for a relatively long time. ${ }^{21,22}$ Therefore, the cultures are more suitable for chronically studying motor neuron properties.
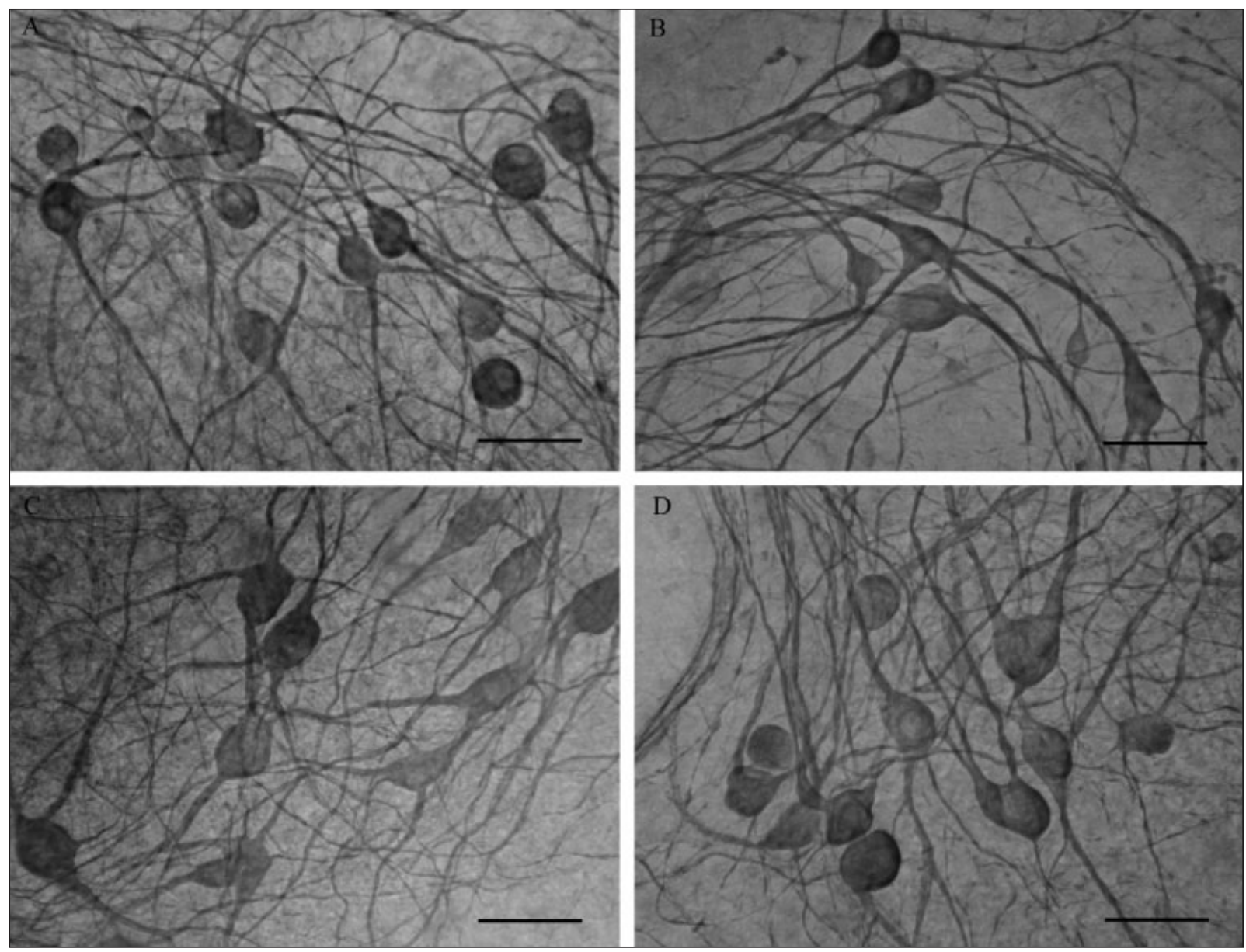

Figure 3: In SMI-32 immunochemistry staining, many motor neurons could be observed. There was little difference between untreated slices $(A)$ and $0.5 \mathrm{mg} / \mathrm{mL} \mathrm{NC} \operatorname{Ig} G(B)$, GBS IgG $(C)$ or $A L S \operatorname{Ig} G(D)$-exposed slices. All were the same magnification. Scale bar $=50$ um. NC, normal control; GBS, Guillain-Barré syndrome; ALS, amyotrophic lateral sclerosis. 


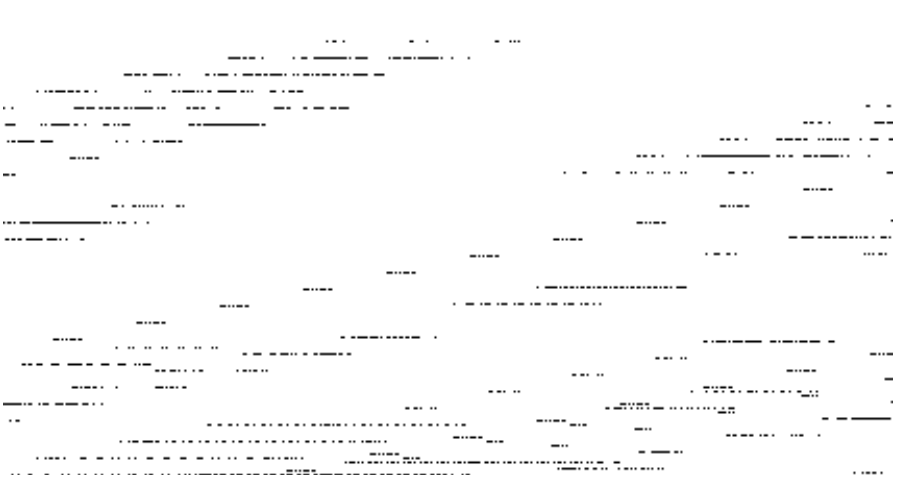

Figure 4: $L D H$ release in cultures treated with $N C, D C$ or $A L S \operatorname{Ig} G$ at $0.05 \mathrm{mg} / \mathrm{mL}, 0.1 \mathrm{mg} / \mathrm{mL}, 0.2 \mathrm{mg} / \mathrm{mL}, 0.3 \mathrm{mg} / \mathrm{mL}$ or $0.5 \mathrm{mg} / \mathrm{mL}$ for three weeks. There was no significant difference in $L D H$ release among the three groups. Data are expressed as percentages (mean \pm SEM) of untreated control. NC IgG, $n=10 ; D C \operatorname{Ig} G, n=8 ; A L S \operatorname{Ig} G, n=12$. NC, normal control; DC, disease control; $A L S$, amyotrophic lateral sclerosis.

For the first time, we used organotypic slice cultures to demonstrate that $\operatorname{IgG}$ from ALS patients treated for three weeks could not induce motor neuron damage. One possible explanation for the phenomenon is that in these six ALS patients autoimmunity did not play a primary role in the pathogenesis. One study demonstrated that sera from only $26 \%$ of patients with sporadic ALS induced apoptosis of a human neuroblastoma cell line in culture and most contained anti-Fas autoantibodies. ${ }^{8}$ This is in agreement with the hypothesis that only some ALS patients may have an immune-mediated disease mechanism.

On the other hand, the results obtained from organotypic slice cultures may differ from those obtained from cell cultures. There is an interesting study about ALS IgG complexes using rat gliamotor neuron cocultures. ${ }^{25}$ In the presence of ALS IgG, motor neurons were noted to be significantly damaged in the microgliamotor neuron cocultures, whereas the same concentrations of ALS IgG had minimal harmful effects when added to motor neuron cultures in the absence of microglia. Additionally, the presence of astrocytes completely reversed the motor neuron damage induced by activated microglia. ${ }^{25}$ Our results obtained from spinal cord organotypic cultures with all three kinds of cells are in line with the report. This also indicates that ALS is a noncell-autonomous disease and glial cells play an important role in the onset and development of ALS.

Several lines of evidence suggest that ALS IgG may exert cytotoxic effects through antibodies against calcium channels ${ }^{14}$ or Fas. ${ }^{8}$ It is worth noting that cell lines possessing corresponding antigens were used in these studies. To guarantee motor neuron survival in vitro, organotypic cultures were derived from early postnatal animals in the present experiment. Because the antigens present on neonatal spinal motor neurons may differ from adult spinal motor neurons, the present study cannot exclude the possibility that ALS IgG may exert toxic effects on adult motor neurons.

In addition, there is another explanation for the results, that is, that IgG does not play an active role in ALS. Several lines of evidence lend support to this opinion. Two independent groups were not able to detect antibodies against voltage-gated calcium channels. ${ }^{17,18}$ Nyormoi suggested that proteases might be partly responsible for some of the effects previously described for ALS IgG. ${ }^{19}$

With respect to the present study, ALS IgG did not induce motor neuron death in organotypic spinal cord slices, but we can not preclude the possibility that other changes may be present in motor neurons. Because organotypic culture has particular advantages, that is, an in vivo horizontal architecture and longterm survival, it lends beneficial support to studying the effect of $\mathrm{IgG}$ in vitro. It is necessary to consider the interactions between cells when we evaluate the impact of $\mathrm{IgG}$ on motor neurons. Herein, our study presents a new way to explore the question. Further studies are needed to clarify the role of autoimmunity in ALS.

\section{ACKNOWLEDGEMENTS}

This work was supported in part by a grant from the Natural Science Foundation of China (30670732).

\section{REFERENCES}

1. Appel SH, Glenn-Smith R, Alexianu M, Siklos L, Engelhardt J, Colom LV, et al. Increased intracellular calcium triggered by immune mechanisms in amyotrophic lateral sclerosis. Clin Neurosci. 1995;3(6):368-74.

2. Engelhardt JI, Appel SH. IgG reactivity in the spinal cord and motor cortex in amyotrophic lateral sclerosis. Arch Neurol. 1990; 47(11):1210-6.

3. Alexianu ME, Kozovska M, Appel SH. Immune reactivity in a mouse model of familial ALS correlates with disease progression. Neurology. 2001;57(7):1282-9.

4. Li F, Pestronk A. Autoantibodies to GM1 ganglioside: different reactivity to GM1-liposomes in amyotrophic lateral sclerosis and lower motor neuron disorders. J Neurol Sci. 1991;104(2): 209-14.

5. Smith RG, Hamilton S, Hofmann F, Schneider T, Nastainczyk W, Birnbaumer L, et al. Serum antibodies to L-type calcium channels in patients with amyotrophic lateral sclerosis. N Engl J Med. 1992;327(24):1721-8.

6. Kimura F, Smith RG, Delbono O, Nyormoi O, Schneider T, Nastainczyk W, et al. Amyotrophic lateral sclerosis patient antibodies label $\mathrm{Ca} 2+$ channel alpha 1 subunit. Ann Neurol. 1994;35(2):164-71.

7. Couratier P, Yi FH, Preud'homme JL, Clavelou P, White A, Sindou $P$, et al. Serum autoantibodies to neurofilament proteins in sporadic amyotrophic lateral sclerosis. J Neurol Sci. 1998; 154(2):137-45.

8. Yi FH, Lautrette C, Vermot-Desroches C, Bordessoule D, Couratier $\mathrm{P}$, Wijdenes $\mathrm{J}$, et al. In vitro induction of neuronal apoptosis by anti-Fas antibody-containing sera from amyotrophic lateral sclerosis patients. J Neuroimmunol. 2000;109(2):211-20.

9. Sengun IS, Appel SH. Serum anti-Fas antibody levels in amyotrophic lateral sclerosis. J Neuroimmunol. 2003;142(12): $137-40$.

10. Engelhardt JI, Siklos L, Komuves L, Smith RG, Appel SH. Antibodies to calcium channels from ALS patients passively transferred to mice selectively increase intracellular calcium and induce ultrastructural changes in motoneurons. Synapse. 1995; 20(3):185-99.

11. Pullen AH, Humphreys P. Ultrastructural analysis of spinal motoneurones from mice treated with IgG from ALS patients, healthy individuals, or disease controls. J Neurol Sci. 2000; 180(1-2):35-45.

12. Obal I, Siklos L, Engelhardt JI. Altered calcium in motoneurons by IgG from human motoneuron diseases. Acta Neurol Scand. 2002;106(5):282-91 
13. Pullen AH, Demestre M, Howard RS, Orrell RW. Passive transfer of purified $\mathrm{IgG}$ from patients with amyotrophic lateral sclerosis to mice results in degeneration of motor neurons accompanied by $\mathrm{Ca} 2+$ enhancement. Acta Neuropathol. 2004;107(1):35-46.

14. Smith RG, Alexianu ME, Crawford G, Nyormoi O, Stefani E, Appel SH. Cytotoxicity of immunoglobulins from amyotrophic lateral sclerosis patients on a hybrid motoneuron cell line. Proc Natl Acad Sci USA. 1994;91(8):3393-7.

15. Alexianu ME, Mohamed AH, Smith RG, Colom LV, Appel SH. Apoptotic cell death of a hybrid motoneuron cell line induced by immunoglobulins from patients with amyotrophic lateral sclerosis. J Neurochem. 1994;63(6):2365-8.

16. Demestre M, Pullen A, Orrell RW, Orth M. ALS-IgG-induced selective motor neurone apoptosis in rat mixed primary spinal cord cultures. J Neurochem. 2005;94(1):268-75.

17. Arsac C, Raymond C, Martin-Moutot N, Dargent B, Couraud F, Pouget $\mathbf{J}$, et al. Immunoassays fail to detect antibodies against neuronal calcium channels in amyotrophic lateral sclerosis serum. Ann Neurol. 1996;40(5):695-700.

18. Drachman DB, Fishman PS, Rothstein JD, Motomura M, Lang B, Vincent A, et al. Amyotrophic lateral sclerosis. An autoimmune disease? Adv Neurol. 1995;68:59-65.
19. Nyormoi O. Proteolytic activity in amyotrophic lateral sclerosis IgG preparations. Ann Neurol. 1996;40(5):701-6.

20. Bär PR. Motor neuron disease in vitro: the use of cultured motor neurons to study amyotrophic lateral sclerosis. Eur J Pharmacol. 2000;405(1-3):285-95.

21. Rothstein JD, Jin L, Dykes-Hoberg M, Kuncl RW. Chronic inhibition of glutamate uptake produces a model of slow neurotoxicity. Proc Natl Acad Sci USA. 1993;90(14):6591-5.

22. Drachman DB, Rothstein JD. Inhibition of cyclooxygenase-2 protects motor neurons in an organotypic model of amyotrophic lateral sclerosis. Ann Neurol. 2000;48(5):792-5.

23. Stoppini L, Buchs PA, Muller D. A simple method for organotypic cultures of nervous tissue. J Neurosci Methods. 1991;37(2): 173-82.

24. Noraberg J, Kristensen BW, Zimmer J. Markers for neuronal degeneration in organotypic slice cultures. Brain Res Brain Res Protoc. 1999;3(3):278-90.

25. Zhao W, Xie W, Le W, Beers DR, He Y, Henkel JS, et al. Activated microglia initiate motor neuron injury by a nitric oxide and glutamate-mediated mechanism. J Neuropathol Exp Neurol. 2004;63(9):964-77. 